IJOTL TL, Vol. 4, No. 1, January 2019

p ISSN: 2502 2326; e ISSN: 2502 8278

Https://soloclcs.org; Email: ijolt1@,gmail.com Center of Language and Cultural Studies, Surakarta, Indonesia

Thamrin, Sehang Nur; Suriaman, Aminah \& Maghfirah. 2019. Students' Perception on the Implementation of Moodle Web Based in Learning Grammar. IJOTL TL (2019), 4(1): 1 10. DOI: 10.30957/ijotl tl.v4i1.552.

\title{
Students' Perception on the Implementation of Moodle Web-Based in Learning Grammar
}

\author{
Nur Sehang Thamrin ${ }^{1}$, Aminah Suriaman ${ }^{2} \&$ Maghfirah $^{3}$ \\ English Study Program, Universitas Tadulako \\ Jl. Soekarno Hatta KM. 9 Palu Sulawesi Tengah \\ 1ursehangthamrin@untad.ac.id \\ 2amisuriaman@gmail.com \\ 3.maghfiradigby@yahoo.com
}

\begin{abstract}
Students in tertiary educational level in Indonesia, particularly at a state university in Centra Sulawesi are required to write a scientific paper as one of the requirements to complete their study period. The government even requires them to publish it in the academic online journal. It means that students construct it in the English language which students consider that writing an English article is difficult. Students produce several grammatical mistakes in their writing. They thought that learning grammar is such a difficult lesson and learning instruction is not interesting as teachers rely on one main resource. Nowadays, based on the researchers' investigation that there are several constraints that make the teaching-learning grammar is not effective and interesting; lack of references, time and space. While students need time to practice the language. Moodle as a part of information technology tools contributes to the solution to that constrain. After experiencing the grammar teaching-learning instruction, most students respond positive view toward the implementation of Moodle in the grammar teaching-learning process. Overall, almost all students respond that online learning instruction is needed.
\end{abstract}

Keywords: information communication technology, moodle, learning grammar, independent learning.

\section{INTRODUCTION}

The skills to write scientific papers are needed by students in completing their studies in college. These skills not only require a set of ideas or thoughts in developing the topic of scientific work, but they can assemble the correct sentences according to the rules used. The composition of sentences that are good and true describe the quality of a scientific work so that it will attract readers.

Without exception, undergraduate students of the English Language Study Program in Indonesia, particularly in Central Sulawesi, are also required to write a scientific paper which is called skripsi in completing their study. The government also requires the graduate students in tertiary level to publish an article journal which is also one of the requirements besides the skripsi (Husin and Nurbayani, 2017). They must make 
IJOTL TL, Vol. 4, No. 1, January 2019

p ISSN: 2502 2326; e ISSN: 2502 8278

Https://soloclcs.org; Email: ijolt1@,gmail.com Center of Language and Cultural Studies, Surakarta, Indonesia

Thamrin, Sehang Nur; Suriaman, Aminah \& Maghfirah. 2019. Students' Perception on the Implementation of Moodle Web Based in Learning Grammar. IJOTL TL (2019), 4(1): 1 10. DOI: 10.30957/ijotl tl.v4i1.552.

scientific papers in English, which is not an easy thing as it needs to meet several writing components; one of which is grammar (Nugraha in Aunurrahman, Hamied, and Emilia, 2017; and Megaiab, 2014). In Indonesia, English subject is a compulsory subject in a curriculum for the high level to tertiary level of education which means English subject must be taught to students since they are at high school. The students have learned how to construct a paragraph with the grammatical component. Furthermore, grammar lesson includes four levels on the syllabus for English Language Study Program. Therefore students are expected to write a paragraph grammatically. However, the fact regarding students' competency in writing a good paragraph is not satisfied yet.

Based on the observation of grammar class subject, learning English grammar is the most difficult component for students who will become the object of research. They need time to practice using the sentence structure continuously. However, the amount of time for that subject is limited so that the students lack opportunities to practice. Basically, there are many resources on the internet that the students may use to practice, but the students' self-study motivation is not yet built. The students lack initiation to do an independent learning. Even though the lecturers have suggested them to be active in finding related reading resources. In addition, the teaching-learning process still relays on the teacher-centered where the teachers explain the material with power point without integrating students actively. It is suggested by Herrington and Kervin (2007) that the use of technology is not only as a means of engaging students in a meaningful and immersive learning environment, but it is also to enable students to use and experience technology as powerful cognitive tools.

Despite the causes mentioned previously -the limited face-to-face in the classroom and the lack of printed resources can be managed by using ICT -Information and Communication Technology (Yunus, Lubis, \& Lin, 2009). In recent years, computerbased or ICT-based learning methods in education have been widely used, from basic level education to higher education (Budianto, 2014). The use of ICT in the teachinglearning process does not only create the joyful learning environment but also can help motivate the students and capture their attention. Students' independent learning can be trained by controlling their participation through the ICT such as web-based application. However, most grammar lecturers in the Teacher Training and Education Faculty of Tadulako University have not implemented ICT-based learning yet (Kervin et al., 2006) in their article argue that "there is minimal evidence of the education implementation of personal-demand technologies" (p.416). Thus, innovation or renewal must be initiated in the classroom. We have to change the learning paradigm from lecturer-centered learning where lecturers give lectures into student-centered learning (SCL) where students construct and discover knowledge (Kassim \& Ali, 2007). There are several strategies to engage students to be more active in doing a learning process which one of them is integrating ICT. In integrating ICT and SCL, a lecturer is the one who acts as a facilitator on how to manage the teaching-learning processes either in a face-to-face meeting or through the use of ICT.

The implementation of ICT has also enabled the use of various types of media simultaneously in the form of e-learning application software that can be accessed for 
IJOTL TL, Vol. 4, No. 1, January 2019

p ISSN: 2502 2326; e ISSN: 2502 8278

Https://soloclcs.org; Email: ijolt1@,gmail.com Center of Language and Cultural Studies, Surakarta, Indonesia

Thamrin, Sehang Nur; Suriaman, Aminah \& Maghfirah. 2019. Students' Perception on the Implementation of Moodle Web Based in Learning Grammar. IJOTL TL (2019), 4(1): 1 10. DOI: 10.30957/ijot1 tl.v4i1.552.

free or paid. E-learning assisted teaching is teaching that combines face-to-face teaching in classrooms and teaching aided computer facilities connected to the internet. The teaching-learning process can be conducted anywhere which is no border of class. This teaching model can optimize many learning resources that are visual, animated, text and images. Even the evaluation of student learning outcomes can be done online (Harmer, 2007). An e-learning application that will be applied in this research is the Moodle application, which has features to support online/e-learning. Moodle stands for Modular Object-Oriented Dynamic Learning Environment which is one of the popular e-learning application. Moodle is a software that gives a solution for creating and organizing online courses via the Internet (Boskovic, Gajic,and Tomic, 2014).

In short, this study investigates whether the implementation of Moodle in teaching grammar class motivates students' independent learning. The result of their motivation can be highlighted through their perception of learning grammar.

\section{REVIEW OF LITERATURE}

Generally, media are tools to convey information from one place to another. In the process of teaching and learning, media are used not only to convey material content from teachers to students but also to create a process of transforming information effectively, efficient and enjoyable. A learning process contains five communication components; teachers, teaching materials, learning media, students, and learning goals (Santyasa, 2007). This proves that learning medium is a unity in the learning process. Therefore, teachers/lecturers must be able to design learning media which are means for learning activities. Good learning media will increase the interest of students to do the learning process in the form of reading, observing, trying, working on questions, and others. The media will eventually stimulate the interests, thoughts, and feelings of students in learning activities to achieve learning goals. Brinton (1991) defines media, "as a tool for language learning/teaching, media has always been present and has facilitated the task of language learning for both instructed and noninstructed learners.

Media can be grouped into two types, namely; nontechnical media and technical media (Brinton, 1991). Non-technical media is a learning medium that can be used by teachers/lecturers with limited electricity or electronic media such as whiteboards, cards, posters, maps, games boards, objects/realia, puppet, brochure, newspaper/magazines. While technical media are in the form of visual media, audio media, audio media visuals, computer software/hardware, and language laboratory.

As an integral part of the learning system, learning media have several functions (Santyasa, 2007) as follows:

1. Learning media can go beyond the boundaries of classrooms as many objects are not possible to be seen directly in the class. Students can be facilitated by video to observe those objects.

2. Learning media gives a solution to limitation or differences experience of learners towards particular events in the past that are not found anymore in the present. Thus the students may have similar knowledge about the past event through videos or pictures. 
IJOTL TL, Vol. 4, No. 1, January 2019

p ISSN: 2502 2326; e ISSN: 2502 8278

Https://soloclcs.org; Email: ijolt1@,gmail.com Center of Language and Cultural Studies, Surakarta, Indonesia

Thamrin, Sehang Nur; Suriaman, Aminah \& Maghfirah. 2019. Students' Perception on the Implementation of Moodle Web Based in Learning Grammar. IJOTL TL (2019), 4(1): 1 10. DOI: 10.30957/ijotl tl.v4i1.552.

3. Learning media can reach a large number of audiences and enable them to observe an object simultaneously. The Interactive learning media allow direct interaction between learners and learning resources and the implementation of learning in accordance with their abilities, interests, and time. With computer-assisted learning modules or packages, students can learn according to the ability, place, time, and speed of each student.

4. Good learning media can provide basic concepts that are true, concrete, and realistic so that the media of learning can provide an integral/comprehensive experience from the concrete to the abstract.

5. Good learning media can stimulate and generate motivation and interest in learning. Audiovisual effects in multimedia can provide a good stimulus to learners' senses.

The use of the internet as a learning medium has long been widely used. Universities, particularly in Central Sulawesi are required to use ICT in the learning process so that the student-centered learning process can be encouraged easily. Education faculty as an institution prepares professional teachers to be prospective teachers who recognize the development of ICT and are skillful in implementing it during the teaching-learning process. There are several studies regarding the use of ICT in the learning process which have been carried out by several researchers. Budianto, (2014) in his study entitled, "Promoting Students' Autonomous Learning through ICT Based Learning in ICP", found out the students have a positive attitude towards the implementation of ICT to perform task learning experience. In addition, Maricic (2012) found out in her research entitled, "The Use of ICT in the Teaching of English Grammar; The views and Experiences of six teachers of English in Sweden" that all respondents are positive towards the use of ICT. Lastly, Aminah (2016) with her research entitled,"Students and Teacher Perception on the Role of ICT in Promoting Instruction for Quality Teaching and Learning in Central Sulawesi, Indonesia found out that web-based instructional materials are effective to promote students' independent learning. In conclusion, the result of previous studies show that the research subjects involved in the study responded well to the use of the internet compared to ordinary or regular learning processes in the classroom

In the era of modern technology, learning not only can be done in the classroom. ICT advances make it possible to design virtual learning processes in the form of elearning. Assisted E-learning is a learning process that combines face-to-face teaching in class and teaching assisted by computer facilities connected to the internet. Elearning teaching can optimize many visual learning resources in the form of videos, texts, and images (Ammanni, and Aparanjani, 2016). Furthermore, teachers can design attractive and joyful learning atmosphere by implementing Web-based instruction which makes students will be easier to get messages and information. Multimedia learning via the Web allows students to access information and learning materials independently and without time limits. Sabar, Kurniawan dan Rahman's (2011) finding added value for students in supporting the process of language learning through the Web (e-learning) is: 
IJOTL TL, Vol. 4, No. 1, January 2019

p ISSN: 2502 2326; e ISSN: 2502 8278

Https://soloclcs.org; Email: ijolt1@,gmail.com Center of Language and Cultural Studies, Surakarta, Indonesia

Thamrin, Sehang Nur; Suriaman, Aminah \& Maghfirah. 2019. Students' Perception on the Implementation of Moodle Web Based in Learning Grammar. IJOTL TL (2019), 4(1): 1 10. DOI: 10.30957/ijotl tl.v4i1.552.

1. Students get more up-to-date information or learning resources easily, faster and more clearly.

2. Students get various types of information and learning materials which are more interesting.

3. The students can develop their English language competency autonomously

4. Students are more active and excited because they are directly involved in the process of getting information and learning materials.

The use of ICT media in learning English has also been known since the 1990s (Schreck, Richard \& Schreck, 1991) known as CALL (Computer Assisted Language Learning). ICT-based learning allows students to do exercises using language independently or in groups. According to Harmer (2007), "teachers can set assignments, have conversations with students and give feedback on the students' work."

ICT is a form of the development and advancement of science and technology that must be used wisely, especially in learning English. Given the role of English as one of the global languages needed for millennia generations in facing global competition. The innovation of ICT-based English learning provides an opportunity for them to improve their competencies on a global scale.

With the various benefits of ICT in the teaching and learning process, a teacher must have a clear goal of utilizing ICT in the teaching and learning process so that ICTs can be used effectively and efficiently. For example in this research, the research team used ICT media to train students' understanding in using some elements of English patterns. Thus the material content and learning activities through ICT media enable students to practice using the sentence pattern independently. Their learning progress is not only controlled by the lecturers but the students themselves.

The content of the material to be taught and the learning objectives that are achieved during this research process is based on the syllabus implemented at English Study Program in one university in Central Sulawesi. It has been packed by the research team. Teaching material is presented in the form of ICT media; powerpoint slides, animations, and movies via the Moodle application that allows students to access material independently. Students may have a discussion with peers and lecturers. Moodle gives an opportunity for students to practice language as it facilitates several tasks and quizzes that can be done by the students independently without being limited by time and space. The use of Moodle makes it easy for both the lecturer and students to monitor students' progress. It is expected that it may stimulate students' self-study. By integrating Moodle in the teaching-learning process, it does not engage students and lecturers in the learning contents but also either lecturer or students can control students' learning progress. The implementation of Moodle during the teaching process is similar to off-line classroom as teachers may explain and even discuss the material presnted in the group discussion. Teaching material, quizzes and assignment are also designed to cover the needs of teaching-learning. 
IJOTL TL, Vol. 4, No. 1, January 2019

p ISSN: 2502 2326; e ISSN: 2502 8278

Https://soloclcs.org; Email: ijolt1@,gmail.com Center of Language and Cultural Studies, Surakarta, Indonesia

Thamrin, Sehang Nur; Suriaman, Aminah \& Maghfirah. 2019. Students' Perception on the Implementation of Moodle Web - Based in Learning Grammar. IJOTL TL (2019), 4(1): 1 10. DOI: 10.30957/ijot1 -1..v4i1.552.

\section{METHODS}

Basically, this study is categorized qualitative R\& D (Research and Development which includes design and development research, namely research used to produce certain products, and test the effectiveness of these products. Products found can be in the form of models, patterns, procedures, systems. In the field of education, products produced through $\mathrm{R} \& \mathrm{D}$ research are expected to increase education productivity, namely graduates who are numerous, qualified, and relevant to needs (Sugiyono, 2014).

However, this article only higlites the students' perception after experiencing the learning process via the Internet; Moodle. It used the qualitative method to analyze data from respondents relating to their perception towards the application of Moodle in teaching and learning grammar in English Study Program in a state university in Central Sulawesi.

Since the use of e-learning, was not familiar to all students of English Study Program, this research only involved 34 respondents who have experienced the use of Moodle during the teaching and learning grammar activities. Then, the data were gathered through a questionnaire given to students via the internet to find out their perceptions towards the application of Moodle during the teaching-learning process. It was not used only investigating students' perception towards the implementation of Moodle but also reveal students perception towards learning grammar before and after the implementation of Moodle during the grammar class. The data were divided into two categories; students' view relating to learning grammar before experiencing Moodle and their perception of learning grammar through Moodle.

\section{RESULTS AND DISCUSSION}

The results and findings are presented into two separate sections. Firstly, the analysis of the data regarding students' view before experiencing Moodle in teachinglearning grammar activities was investigated. In the second part, the results are categorized according to students' perception towards the implementation of Moodle in teaching-learning grammar process.

\subsection{Students' view of Learning English Grammar}

This part of the questionnaire includes two items which were related to the students' view of learning English grammar before the implementation of Moodle duringthe teaching-learning process. Figure 1 shows data relating their responses towards their experience learning grammar through the conventional teaching-learning process. 
IJOTL TL, Vol. 4, No. 1, January 2019

p ISSN: 2502 2326; e ISSN: 2502 8278

Https://soloclcs.org; Email: ijolt1@,gmail.com Center of Language and Cultural Studies, Surakarta, Indonesia

Thamrin, Sehang Nur; Suriaman, Aminah \& Maghfirah. 2019. Students' Perception on the Implementation of Moodle Web Based in Learning Grammar. IJOTL TL (2019), 4(1): 1 10. DOI: 10.30957/ijot1 tl.v4i1.552.

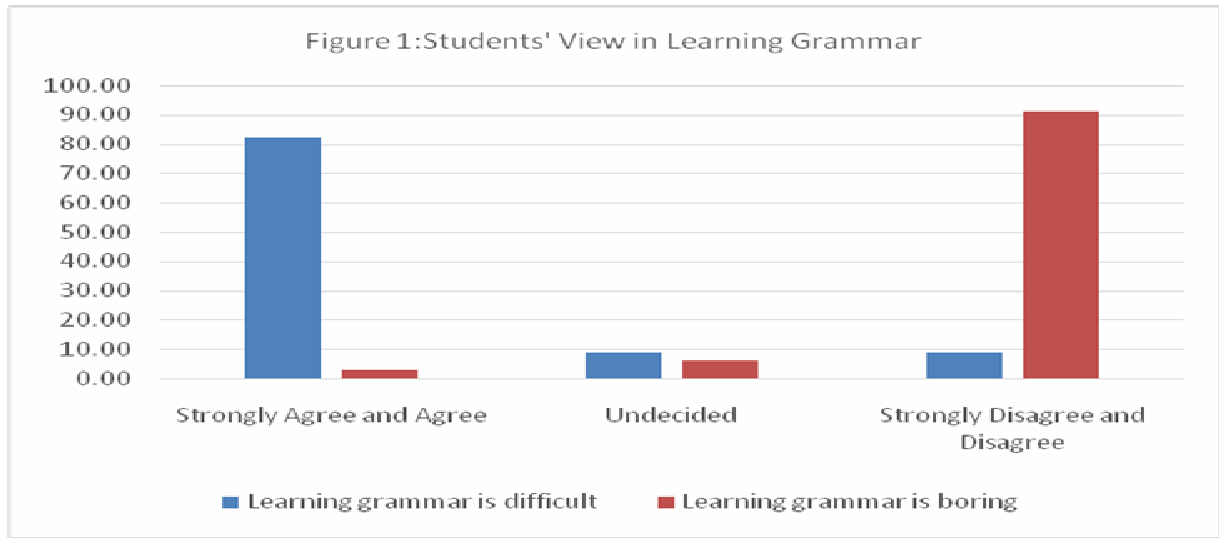

Based on the chart, it could be seen that students find it difficult to study the grammar lesson. This view proves the preliminary data towards students' ability in writing. Even though they have learned English grammar for years, they still find it difficult to construct grammatical sentences. As a result, students comment that learning grammar is boring. These findings indicate that effective teaching media are somehow urged to assist students to learn grammar. Moodle is assumed to give a positive contribution in relation in time and space issues as students can practice to use language independently wherever and anytime they have.

\subsection{Students' view towards the Implementation of Moodle}

This part aims at exploring the students' view toward the implementation of Moodle during the teaching-learning grammar process. Data gathered inform how to moodle support students the learn independently, particularly learning grammar. I assume that learning grammar is not like a magic which can be wiggled a magic stick once and come up with the outstanding result, but it needs effective teaching strategies and practices. Moodle is an Open-Source Learning Management System that is used tens of millions of people worldwide (lambasolution). It stands for Modular Object-Oriented Dynamic Learning Environment which can be integrated with online content resources. That is the way it gives the solution toward the constraints of teaching-learning conditions in term of the number of resources available at schools/colleges, time, and space as it can be used to conduct online courses. Furthermore, it supports face-to-face teaching-learning process as it can be extended for modules, assignments, quizzes, grading, and even discussion. On the other word, it can build collaborative teachinglearning among students and even among students and teacher.

The researchers have designed several modules and quizzes and assignment that support students to learn independently. The modules are presented in form of attractive power point presentation which make students are easy to understand the content of the materials provided. As a result, it is found through the data that $91,18 \%$ of the respondents strongly agree and agree that powerpoint presentation makes them easy to understand the lesson. Then, Table 1 shows that 94,12\% of students responded that Moodle is an interesting model to learn English grammar. This way give a solution 
IJOTL TL, Vol. 4, No. 1, January 2019

p ISSN: 2502 2326; e ISSN: 2502 8278

Https://soloclcs.org; Email: ijolt1@gmail.com

Center of Language and Cultural Studies, Surakarta, Indonesia

Thamrin, Sehang Nur; Suriaman, Aminah \& Maghfirah. 2019. Students' Perception on the Implementation of Moodle Web Based in Learning Grammar.

IJOTL TL (2019), 4(1): 1 10. DOI: 10.30957/ijot1 tl.v4i1.552.

towards the reality that a limited number of teacher teachers grammar class via power point presentation. They rely on the textbook that is used every semester.

Another obstacle of the teaching-learning process is time allocated for face-to-face meeting per week. It has been observed that it does not give chances for students to practice the use of language. Instead of giving conventional sort of homework, the researchers have designed moodle layout with several assignments and quizzes that give opportunities for students to practice the use of language grammatically correct independently anywhere and anytime. Figure 1 illustrates that 88,24 \% responds that they have chances to practice language via Moodle as it presents several quizzes and assignments. They may also have a discussion among them or with teachers based on their availability. As the result, this model trains the students the learn independently. There is $94,12 \%$ of students responded that teaching-learning via moodle is effective and efficient as they can learn anywhere and anytime. In addition, by doing assignments and quizzes via Moodle, the students can assess their shelves as the scoring rubric has been set. Students may control their study progress. So that students' progress study is not controlled by the teacher only. It is automatically that students have conducted the self-assessment process.

Table 1: Students' View toward the Implementation of Moodle

\begin{tabular}{lrrr}
\hline Statements & $\begin{array}{c}\text { Strongly } \\
\text { Agree and } \\
\text { Agree (\%) }\end{array}$ & $\begin{array}{r}\text { Undecided } \\
\text { (\%) }\end{array}$ & $\begin{array}{c}\text { Strongly } \\
\text { disagree } \\
\text { and } \\
\text { Disagree(\%) }\end{array}$ \\
\hline $\begin{array}{l}\text { Using PowerPoint Presentation makes you easy to } \\
\text { understand the lesson }\end{array}$ & 91,18 & 5,88 & 2,94 \\
$\begin{array}{l}\text { You enjoy being taught via 'Moodle" in grammar } \\
\text { class }\end{array}$ & 94,12 & 2,94 & 2,94 \\
$\begin{array}{l}\text { Group discussion in "Moodle" is effective to } \\
\text { strengthen your understanding }\end{array}$ & 94,12 & 2,94 & 2,94 \\
$\begin{array}{l}\text { Group discussion via "Moodle" makes you } \\
\text { confident to share your idea }\end{array}$ & 91,18 & 2,94 & 5,88 \\
$\begin{array}{l}\text { Teaching-learning via "Moodle" is effective and } \\
\text { efficient as you may study anywhere and anytime }\end{array}$ & 94,12 & 5,88 & 0,00 \\
$\begin{array}{l}\text { You enjoy submitting your assignment via Moodle } \\
\text { Submitting your assignment via Moodle is } \\
\text { effective as you can get the result sooner }\end{array}$ & 94,12 & 2,94 & 2,94 \\
$\begin{array}{l}\text { You improve your performance by using } \\
\text { "Moodle" as provided by several quizzes } \\
\text { to practice }\end{array}$ & 97,06 & 2,94 & 0,00 \\
$\begin{array}{l}\text { Overall, learning grammar via "Moodle" is } \\
\text { interesting }\end{array}$ & 88,24 & 8,82 & 2,94 \\
$\begin{array}{l}\text { In the digital era, you prefer online learning } \\
\text { process }\end{array}$ & & & 2,94 \\
\hline
\end{tabular}


IJOTL TL, Vol. 4, No. 1, January 2019

p ISSN: 2502 2326; e ISSN: 2502 8278

Https://soloclcs.org; Email: ijolt1@gmail.com Center of Language and Cultural Studies, Surakarta, Indonesia

Thamrin, Sehang Nur; Suriaman, Aminah \& Maghfirah. 2019. Students' Perception on the Implementation of Moodle Web Based in Learning Grammar. IJOTL TL (2019), 4(1): 1 10. DOI: 10.30957/ijot1 tl.v4i1.552.

If the students were asked about the advantage of group discussion via Moodle, they give a positive response. 94,12\% students respond that it is effective to strengthen students' understanding relating to the material discussed and $91,18 \%$ students chose that the students are confident to share their idea via moodle group discussion as students have prepared the argument they need to share in the group. In the conventional teaching-learning model, students tend to be reluctant to speak as they take seconds to think the argument to share in the class.

Overall, less than $3 \%$ of students state that learning grammar via moodle is not interesting. It indicates that students achieve various benefits of learning via online courses. As all students prefer online learning process; $100 \%$, it is suggested all courses should be instructed via blended-learning method. Moodle is one of the media which support the implementation of blanded-learning instruction. In the revolution of 4.0, students are encouraged to be used in the application of technology.

\section{CONCLUSION}

It could be denied that the information technology offers the positive contribution in education. Teaching-learning constraints; lack of references, time and space, can be solved via the implementation of technology which is Moodle is a sort of it. as Moodle is provided tools that makes teachers are creative to design online teaching-learning courses, it supports face-to-face meeting. From the obtained data, almost no respondents give a negative view of the implementation of Moodle. They consider previously that the teaching-learning grammar is difficult and boring subject. However, after experiencing learning via Moodle, almost all students respond that teaching-learning grammar via moodle is effective, efficient, and interesting. As the result, all students prefer to teaching-learning instruction via online. It is suggested that blended-learning should be encouraged.

\section{ACKNOWLEDGMENTS}

This research cannot be carried out without the help of all parties; the rector of Tadulako University, the dean of the Education Faculty, colleagues and students as research respondents. This research was carried out with the help of funds that had been allocated through DIPA FKIP UNTAD in 2018. Therefore, we would like to thank all those who have helped the implementation of this research.

\section{REFERENCES}

Suriaman., A.. (2016). Students and Teacher Perception on the Role of ICT in Promoting Instruction for Quality Teaching and Learning in Central Sulawesi,Indonesia. Asian EFL, 1 .

Ammanni, and Aparanjani, U. (2016). The Role of ICT in English Language Teaching and Learning. International Journal of Scientific and Engineering Research, 7(7).

Aunurrahman, Hamied, F.A., A., \& Emilia, E. (2017). Exploring The Tertiary EFL Students ', 7(1), 72-79. 
IJOTL TL, Vol. 4, No. 1, January 2019

p ISSN: 2502 2326; e ISSN: 2502 8278

Https://soloclcs.org; Email: ijolt1@gmail.com

Center of Language and Cultural Studies, Surakarta, Indonesia

Thamrin, Sehang Nur; Suriaman, Aminah \& Maghfirah. 2019. Students' Perception on the Implementation of Moodle Web Based in Learning Grammar. IJOTL TL (2019), 4(1): 1 10. DOI: 10.30957/ijot1 tl.v4i1.552.

Boskovic, V., Gajic, T., and Tomic, I. (2014). Moodle In English Language Teaching. Sinteza,Internet and Education, 480-483. https://doi.org/10.15308/SInteZa-2014480-483

Brinton, D. M. (1991). The Use of Media in Language Teaching. In M. Celce-Murcia (Ed.), Teaching English as a Second and Foreign Language (2nd ed., pp. 454485). Boston: Heinle \& Heinle Publishers.

Budianto, L. (2014). Promoting Students' Autonomous Learning through ICT Based Learning in ICP: A Case Study. LINGUA, 9(2), 125-134.

Harmer, J. (2007). The Practice of English Language Teaching (4th ed.). London: Person Education Limited.

Herrington, J. and Kervin, L. (2007). Authentic learning supported by technology: 10 suggestions and cases of integration in classrooms, 44(3), 219-236.

Husin, M.S and Nurbayani, E. (2017). The Ability of Indonesian EFL Learners in Writing Academic Papers, 17(2), 237-250.

Kassim, H., \& Ali, Z. (2007). The Use of ICT in the Implementation of StudentCentered Learning (SCL). Internet Journal of E-Language Learning \& Teaching, $4(1), 15-31$.

Kervin, L. K., Reid, D., Vardy, J., Hindle, C., Kervin, L., Reid, D., ... Hindle, C. (2006). A partnership for iPod pedagogy: using the technology of millennial learners across educational contexts of millennial learners across educational contexts, 419-422.

Maricic, I. (2012). The Use of ICT in the Teaching of English Grammar. Sweden: Linnaeus University: School of Language and Literature.

Megaiab, M. M. A. (2014). The English Writing Competence of the , (2000), 187-192.

Sabar, Kurniawan dan Rahman, A. (2011). Penggunaan Web (E-Learning) dalam Proses Pembelajaran Bahasa Inggris di Briton International Eglish School Makkasar. Komunikasi KAREBA, 1(4), 444-456.

Santyasa, I. W. (2007). Landasan Konseptual Media Pembelajaran. Banjar Angkan Klungkung.

Schreck, Richard dan Schreck, J. (1991). Computer-Assisted Language Learning. In Teaching English as a Second and Foreign Language (pp. 472-487).

Sugiyono. (2014). Metode Penelitian Kuantitatif Kualitatif dan R\&D. Bandung: Alfabeta.

Yunus, M. M., Lubis, M. A., \& Lin, C. P. (2009). Language Learning via ICT: Uses, Challenges, and Issues. Information Science and Applications, 6(9), 1453-1467. 